\title{
The Voice of Europe Session of the 4th Annual Congress of the European Association of Societies of Aesthetic Plastic Surgery (EASAPS)
}

\author{
Cristino Suárez López de Vergara • \\ Member of Executive Committee of EASAPS
}

Published online: 1 June 2012

(c) Springer Science+Business Media, LLC and International Society of Aesthetic Plastic Surgery 2012

On 30 September and 1 October 2011, the 4th European Association of Societies of Aesthetic Plastic Surgery (EASAPS) meeting was held in the Italian city of Milano. The EASAPS meeting took place after the 60th Italian Society of Plastic, Reconstructive, and Aesthetic Surgery (SICPRE) Congress. Dr. Andrea Grisotti was President for both Congresses, and the events were developed at the Marriot Hotel.

It is important to explain what the Voice of Europe is. Each country selects its best work in aesthetic plastic surgery, and these are then presented at the yearly EASAPS Congress. Such works are known as the Voice of Europe.

During the Milano Congress, the Voices of Europe were presented. Each work's quality, presentation, content, and development were assessed by all the Executive Committee members of EASAPS. Animation Deformities of the Pectoralis Muscle: The Cinderella of Submuscular Mammaplasty by M. Pelle Ceravolo, representing Italy, turned out to be the best work. This work was awarded with the first edition of the Ulrich Hinderer Prize, which was created to honour the memory of Professor Ulrich Hinderer.

The EASAPS General Assembly, led by Professor Norbert Pallua (EASAPS President) and Professor Toma Mugea (EASAPS General Secretary), accepted the new-country members from Austria, Belgium, Belarus, Denmark, Greece, Georgia, and Ireland. At the same time, the Scientific Chairman (Dr. Isabel de Benito from Spain) and the Treasurer (Dr. Magnus Noah from Germany) were elected.

The 5th EASAPS Congress (20 June 2012) will be held in Istanbul, and the 4th International Eurasian Aesthetic Plastic Surgery Course (16-19 June 2012) will take place there as well.

Finally, it is important to note that the EASAPS still is growing regarding the number of countries, and very soon, all European countries will belong to the Association.
C. Suárez López de Vergara $(\bowtie)$

Cirugía Plástica y Estética, Av. La Asunción, 30-28 izq., Santa

Cruz, Tenerife, Spain

e-mail: cristinosuarez@gmail.com 